Supporting Information for

\title{
Recovery of Nano-Structured Silicon from End-Of-Life Photovoltaic Wafers with Value-Added Applications in Lithium-Ion Battery
}

Nicolas Eshraghi ${ }^{\dagger}$, Loris Berardo ${ }^{\dagger}$, Audrey Schrijnemakers ${ }^{\dagger}$, Vincent Delaval ${ }^{\dagger}$, Mahdokht

Shaibani *, Mainak Majumder ${ }^{*}$, Rudi Cloots ${ }^{\dagger}$, Bénédicte Vertruyen ${ }^{\dagger}$, Frédéric Boschini ${ }^{\dagger}$, Abdelfattah Mahmoud ${ }^{{ }^{*}}$

${ }^{\dagger}$ GREENMAT, CESAM Research Unit, Department of Chemistry, University of Liege, 4000 Liege, Belgium

${ }^{\ddagger}$ Nanoscale Science and Engineering Laboratory (NSEL), Department of Mechanical and Aerospace Engineering, Monash University, Clayton, VIC 3168, Australia

*The author to whom correspondence should be addressed: Abdelfattah Mahmoud E-mail: Abdelfattah.Mahmoud@uliege.be

Number of pages: 25

Number of Tables: 5

Number of Figures: 12 


\section{List of Tables:}

Table S1. Results of leaching carried out on photovoltaic cells using different leaching solutions. " $X "$ indicates an inconclusive result, " $\sim$ " a partial result, $" \checkmark "$ a conclusive result and "/" refers to unobserved results.

Table S2. ICP-MS results illustrating the $\mathrm{wt} \%$ of each element present in silicon wafers corresponding to each leaching treatment. The unleached sample correspond to feedstock.

Table S3. Chemical method of recovery of metals from photovoltaic panels, an overview of the leaching solutions with the targeted material in the process

Table S4. Recycling rate of $\mathrm{Si}, \mathrm{Al}$ and $\mathrm{Ag}$ at each step of leaching

Table S5. Comparison between the electrochemical performances of the Si material prepared in this work and commercial/synthesized $\mathrm{Si}$ anode material for $\mathrm{Li}$-ion batteries.

\section{List of Figures:}

Figure S1. SEM images of back/bottom side of silicon wafer a) before and b) after $\mathrm{KOH}$ leaching.

Figure S2. SEM images and EDS spectra of back side of silicon wafer a) before and b) after $\mathrm{KOH}$ leaching.

Figure S3. SEM images and EDS spectra of front side of silicon wafer a) before and b) after $\mathrm{HNO}_{3}$ leaching

Figure S4. SEM images and EDS spectra of a) pre-grinded Si and b) L-300 sample (ball milling at $300 \mathrm{rpm}$ for $20 \mathrm{~h}$. 
Figure S5. Effect of the ball milling speed: Cumulative volume size distribution of a) unleached Si powder (UL) and b) leached Si powder (L) after 20h of milling at different speeds from 100 rpm to $400 \mathrm{rpm}$. The Evolution of the characteristic sizes $\left(d_{10}, d_{50}\right.$ and $\left.d_{90}\right)$ of unleached and leached Si milled after 20h of milling at different speeds from $100 \mathrm{rpm}$ to $400 \mathrm{rpm}$.

Figure S6. SEM and TEM images of L-250 samples showing the presence of nanoparticles along with micrometric/sub-micrometric particles.

Figure S7. Voltage profile recorded at $0.05 \mathrm{C}$ of $1^{\text {st }}, 2^{\text {nd }}, 3^{\text {rd }}, 10^{\text {th }}$ and $50^{\text {th }}$ cycles in unleached samples U-150, U-250 and U-350.

Figure S8. Voltage profile recorded at $0.05 \mathrm{C}$ of first lithiation and following cycle in a) unleached samples UL-150, UL-250 and UL-350; b) leached samples L-150, L-250 and L-350.

Figure S9. SEM images of leached Si based electrodes a) before cycling, b) after lithiation, and c) after delithiation.

Figure S10. Effect of Ball milling duration: a) Similar XRD patterns were obtained for all the milled powders with BPR Ratio=10. b) SEM images of the recovered silicon milled during different durations which ranged from 1 to $40 \mathrm{~h}$, for BPR ratio $=10$ show quite similar morphologies at each time step to samples milled with $\mathrm{BPR}=5$.

Figure S11. The particle-size distribution of the recovered silicon milled during different durations which ranged from 1 to $40 \mathrm{~h}$ with a) 5 and b) 10 ball-to-powder ratios.

Figure S12. Evolution of the characteristic sizes $\left(\mathrm{d}_{10}, \mathrm{~d}_{50}\right.$ and $\left.\mathrm{d}_{90}\right)$ of Si milled during different durations (1 to 40h) with BPR: 5 and BPR: 10. 
Leaching of the solar cells. The leaching treatment is performed on polycrystalline silicon wafer from photovoltaic cells. Wafer fragments were inserted in leaching solutions to investigate the efficiency for the removal of a selected target material. As presented in Table $\mathbf{S 1}, \mathrm{NH}_{4} \mathrm{OH}, \mathrm{HCl}$, $\mathrm{KOH}$ and $\mathrm{HNO}_{3}$ were investigated as potential leaching solutions by varying the concentration and temperature of the leaching solution and the total leaching time. $\mathrm{HCl}$ and $\mathrm{KOH}$ are both efficient for the removal of $\mathrm{Al}$ from the back-end layer and $\mathrm{HNO}_{3}$ for removing $\mathrm{Ag}$, $\mathrm{Sn}$ and $\mathrm{Pb}$ from the front side electrodes. ICP-MS was further used to verify the silicon purity and effectiveness of leaching process.

Table S1. Results of leaching carried out on photovoltaic cells using different leaching solutions. " $X$ " indicates an inconclusive result, " $\sim$ " a partial result, " $\vee$ " a conclusive result and "/" refers to unobserved results.

\begin{tabular}{|c|c|c|c|c|c|c|c|c|}
\hline \multirow{2}{*}{$\begin{array}{l}\text { Leaching } \\
\text { solution }\end{array}$} & \multirow{2}{*}{$\begin{array}{c}\text { Concentration } \\
(\mathrm{mol} / \mathrm{l})\end{array}$} & \multirow{2}{*}{$\begin{array}{c}\text { Temperature } \\
\left({ }^{\circ} \mathrm{C}\right)\end{array}$} & \multirow{2}{*}{ Target material } & \multicolumn{5}{|c|}{ Leaching duration (min) } \\
\hline & & & & 5 & 15 & 30 & 45 & 60 \\
\hline \multirow{2}{*}{$\mathrm{NH}_{4} \mathrm{OH}$} & \multirow{2}{*}{7} & RT & \multirow{2}{*}{ I } & $x$ & $x$ & $x$ & $x$ & $x$ \\
\hline & & 40 & & $X$ & $x$ & $X$ & $x$ & $X$ \\
\hline \multirow{3}{*}{$\mathbf{H C l}$} & 1 & RT & $\mathrm{Al}$ & $x$ & $x$ & $x$ & $\checkmark$ & $\checkmark$ \\
\hline & 3 & RT & $\mathrm{Al}$ & 1 & $\checkmark$ & $\checkmark$ & $\checkmark$ & $\checkmark$ \\
\hline & 6 & RT & $\mathrm{Al}$ & 1 & $\checkmark$ & $\checkmark$ & $\checkmark$ & $\checkmark$ \\
\hline \multirow{2}{*}{ КОН } & \multirow{2}{*}{8} & RT & $\mathrm{Al}$ & $\sim$ & $\sim$ & $\sim$ & $\checkmark$ & $\checkmark$ \\
\hline & & 60 & $\mathrm{Al}$ & $\checkmark$ & $\checkmark$ & $\checkmark$ & $\checkmark$ & $\checkmark$ \\
\hline \multirow{3}{*}{$\mathrm{HNO}_{3}$} & 5 & 80 & $\mathrm{Ag}, \mathrm{Sn}, \mathrm{Pb}$ & $X$ & $X$ & $X$ & $X$ & $X$ \\
\hline & \multirow{2}{*}{8} & RT & $\mathrm{Ag}, \mathrm{Sn}, \mathrm{Pb}$ & $x$ & $x$ & $x$ & $x$ & $\checkmark$ \\
\hline & & 80 & $\mathrm{Ag}, \mathrm{Sn}, \mathrm{Pb}$ & 1 & $\checkmark$ & $\checkmark$ & $\checkmark$ & $\checkmark$ \\
\hline
\end{tabular}




\section{Inductively coupled plasma mass spectrometry (ICP-MS)}

In order to prepare the samples to be measured in ICP-MS, wafer fragments of approximately 2 $\mathrm{cm} \times 2 \mathrm{~cm}$ size, resulting from the various leaching steps, are grinded separately in an agate mortar. These powders are then dissolved in 50ml hydrofluoric acid. The atoms in the sample are ionized by injecting the solution into a plasma torch. Then, the resulting plasma is detected and analyzed by mass spectrometry to separate and quantify the different ions present in the sample. For each selected leaching condition, three samples were prepared to ensure consistency of results.

Table S2. ICP-MS results illustrating the wt $\%$ of each element present in silicon wafers corresponding to each leaching treatment. The unleached sample correspond to feedstock.

\begin{tabular}{ccccc}
\hline Leaching solution & Si & Al & Pb & Ag \\
\hline Unleached & 91.586 & 6.819 & 0.044 & 1.551 \\
\hline $\mathrm{HCl}$ leached & 99.455 & 0.051 & 0.004 & 0.49 \\
\hline $\mathrm{HCl} / \mathrm{HNO}_{3}$ leached & 99.993 & 0.005 & 0.001 & 0.001 \\
\hline $\mathrm{KOH}$ leached & 98.403 & 0.027 & 0.026 & 1.544 \\
\hline $\mathrm{KOH} / \mathrm{HNO}_{3}$ leached & 99.99 & 0.007 & 0.001 & 0.002 \\
\hline
\end{tabular}

ICP-MS quantification of aluminum for $\mathrm{KOH}$ and $\mathrm{HCl}$ treatments indicates similar results (Table S2), meaning that both compounds are equally effective in leaching aluminum. Regarding the complete procedures $\left(\mathrm{HCl} / \mathrm{HNO}_{3}\right.$ and $\left.\mathrm{KOH} / \mathrm{HNO}_{3}\right)$, we note that they result in a silicon purity percentage close to $100 \%$. The procedure using hydrochloric acid is discarded due to possible formation of $\mathrm{Cl}_{2}$ gas and limitations for industrial applications. Another hazardous material with limitation for industrial scale application is HF which is used in a large number of approaches to recycle Si from PV wastes (Table $\mathbf{S 3}$ ). 
Table S3. Chemical method of recovery of metals from photovoltaic panels, an overview of the leaching solutions with the targeted material in the process

\begin{tabular}{|c|c|c|c|}
\hline $\begin{array}{c}\text { Target } \\
\text { material }\end{array}$ & & Leaching solution & Ref. \\
\hline $\mathrm{Ag}$ & \multicolumn{2}{|c|}{$40 \%$ aq $\mathrm{HNO}_{3}$ at $40^{\circ} \mathrm{C}$} & \multirow{3}{*}{$\begin{array}{l}\text { E. } \\
\text { Klugmann- } \\
\text { Radziemska } \\
\text { et al. }(2010)^{1}\end{array}$} \\
\hline $\mathrm{Al}$ & \multicolumn{2}{|c|}{$30 \%$ aq solution of $\mathrm{KOH}$ at $80^{\circ} \mathrm{C}$} & \\
\hline $\begin{array}{l}\text { AR coating, } \\
\text { p-n junction }\end{array}$ & \multicolumn{2}{|c|}{$\begin{array}{l}83.33 \mathrm{ml} \mathrm{HNO} \mathrm{HN}_{3}(65 \%)+50 \mathrm{ml} \mathrm{HF}(40 \%)+50 \mathrm{ml} \text { acetic acid }\left(\mathrm{CH}_{3} \mathrm{COOH}\right)(99.5 \%)+1 \mathrm{ml} \mathrm{Br}_{2} \\
\text { For Multi } \mathrm{Si}\left(10 \mathrm{~min} \text { at } 70^{\circ} \mathrm{C}, 5 \mathrm{~min} \text { at } 80^{\circ} \mathrm{C}\right) \\
\text { For Mono } \mathrm{Si}\left(122 \mathrm{~min} \text { at } 80^{\circ} \mathrm{C}\right)\end{array}$} & \\
\hline $\begin{array}{l}\text { Ag electrodes, } \\
\text { AR coating, } \\
\text { emitter layer, } \\
\text { and p-n } \\
\text { junction }\end{array}$ & \multirow[t]{2}{*}{ Mixture 1} & $\begin{array}{l}\left.60 \% \text { nitric acid }\left(\mathrm{HNO}_{3}\right) \text { and } 49 \% \text { hydrofluoric acid (HF) (mixing ratio in vol\%: } 4: 1\right) \text { at } \\
\text { room temperature for } 60 \mathrm{~s}\end{array}$ & \multirow[t]{4}{*}{$\begin{array}{l}\text { J. Park et al. } \\
(2014) \text {, } \\
\text { Shin et al } \\
(2017)^{3} \text {. }\end{array}$} \\
\hline Al electrode & & $30 \%$ potassium hydroxide $(\mathrm{KOH})$ at $80^{\circ} \mathrm{C}$ for $6 \mathrm{~min}$ & \\
\hline $\begin{array}{l}\text { AR Coating, } \\
\text { Al back contact }\end{array}$ & \multirow[b]{2}{*}{ Mixture 2} & $90 \%$ phosphoric acid $\left(\mathrm{H}_{3} \mathrm{PO}_{4}\right)$ at $160^{\circ} \mathrm{C}$ for $60 \mathrm{~min}$ & \\
\hline $\begin{array}{l}\text { Ag electrodes, } \\
\text { emitter layer, } \\
\text { p-n junction }\end{array}$ & & $\mathrm{HF}+\mathrm{HNO}_{3}$ mixed solution for $60 \mathrm{~s}$ & \\
\hline Al metal & \multicolumn{2}{|c|}{$30 \%$ aq $\mathrm{KOH}$ at $60-80^{\circ} \mathrm{C}$, for $2-3 \mathrm{~min}$} & \\
\hline $\begin{array}{l}\text { Ag coatings, } \\
\text { AR coatings, } \\
\text { n-p junctions }\end{array}$ & \multicolumn{2}{|c|}{$250 \mathrm{ml} \mathrm{HNO}_{3}(65 \%): 150 \mathrm{ml} \mathrm{HF}(40 \%): 150 \mathrm{ml} \mathrm{CH}_{3} \mathrm{COOH}(99.5 \%)+3 \mathrm{ml} \mathrm{Br}_{2}$ at $40^{\circ} \mathrm{C}$, time $9 \mathrm{~s}$} & $\begin{array}{l}\text { Klugmann- } \\
\text { Radziemska } \\
\text { et al. }(2010)^{4}\end{array}$ \\
\hline $\begin{array}{l}\text { metal } \\
\text { electrodes, } \\
\text { AR coating, } \\
\text { p-n junction } \\
\text { layer }\end{array}$ & \multicolumn{2}{|c|}{ Mixture of $\mathrm{HF}, \mathrm{HNO}_{3}$, sulfuric acid $\left(\mathrm{H}_{2} \mathrm{SO}_{4}\right),\left(\mathrm{CH}_{3} \mathrm{COOH}\right)$ and distilled water for $20 \mathrm{~min}$} & $\begin{array}{l}\text { S. Kang et al. } \\
(2012)^{5}\end{array}$ \\
\hline $\begin{array}{l}\mathrm{Al}, \mathrm{Ag}, \mathrm{AR} \\
\text { coating }\end{array}$ & \multicolumn{2}{|c|}{ Mixed acid solution of $\mathrm{HNO}_{3}$ and $\mathrm{HF}$ at a ratio of 83:17 } & $\begin{array}{l}\text { Jun-Kyu Lee } \\
\text { et al. }(2017)^{6}\end{array}$ \\
\hline $\mathrm{Al}, \mathrm{Ag}, \mathrm{N}$ & \multicolumn{2}{|c|}{$\begin{array}{l}\text { Leaching at } 20-40^{\circ} \mathrm{C} \text {, using either hydrochloric, sulfuric and nitric acid, or caustic } \mathrm{NaOH} \text {, under ultrasonic } \\
\text { treatment. The concentration of the acids used was varied from } 1 \text { to } 3 \mathrm{M} \text { and treatment time was within } 2 \mathrm{~h} \\
\text { smelting of the }\left(\mathrm{HNO}_{3} / \mathrm{NaOH}\right) \text {-treated materials at } 1520^{\circ} \mathrm{C} \text { with } \mathrm{CaO}-\mathrm{CaF}_{2}-\mathrm{SiO}_{2} \text { is used to scavenge all } \\
\text { metal impurities to produce } \\
>99.998 \% \mathrm{Si}\end{array}$} & $\begin{array}{l}\text { Y. K. Yi et } \\
\text { al. }(2014)^{7}\end{array}$ \\
\hline $\begin{array}{l}\mathrm{Al}, \mathrm{Ag}, \mathrm{AR} \\
\text { coating, } \mathrm{Si}\end{array}$ & \multicolumn{2}{|c|}{$\begin{array}{l}\text { Etching solution prepared by mixing } 26.45 \mathrm{kmol} / \mathrm{m}^{3} \text { of hydrofluoric acid }(\mathrm{HF}), 13.00 \mathrm{kmol} / \mathrm{m}^{3} \text { of nitric } \\
\text { acid and deionized water }\end{array}$} & $\begin{array}{l}\text { K. Takami et } \\
\text { al. }(2015)^{8}\end{array}$ \\
\hline Ag Electrode & \multicolumn{2}{|c|}{$60 \%$ nitric acid $\left(\mathrm{HNO}_{3}\right)$ at room temperature, time $120 \mathrm{~s}$} & J. Park et al. \\
\hline $\begin{array}{l}\text { ARC, emitter, } \\
\text { p-n junction }\end{array}$ & \multicolumn{2}{|c|}{$\begin{array}{l}\text { mechanical removal at } 20 \text { revolutions per minute (RPM) for } 20 \text { min using green fine silicon carbide } \\
\text { powder (\#600) }\end{array}$} & $(2016)^{9}$ \\
\hline $\mathrm{Al}$ & \multicolumn{2}{|c|}{$45 \%$ potassium hydroxide $(\mathrm{KOH})$ at $80^{\circ} \mathrm{C}$, time $10 \mathrm{~min}$} & \\
\hline $\begin{array}{l}\text { SiNx }(\mathrm{AR} \\
\text { coating })\end{array}$ & \multicolumn{2}{|c|}{$90 \%$ phosphoric acid $\left(\mathrm{H}_{3} \mathrm{PO}_{4}\right)$ solution at $160^{\circ} \mathrm{C}$ for $60 \mathrm{~min}$} & $\begin{array}{l}\text { B. Jung et al. } \\
(2016){ }^{10}\end{array}$ \\
\hline $\mathrm{Al}$ & \multicolumn{2}{|c|}{$45 \%$ potassium hydroxide $(\mathrm{KOH})$ solution at $80^{\circ} \mathrm{C}$ for $10 \mathrm{~min}$} & \\
\hline $\mathrm{Cu}$ & \multicolumn{2}{|c|}{$\mathrm{HNO}_{3}$, LIX84-I and $150 \mathrm{~g} / \mathrm{L} \mathrm{H}_{2} \mathrm{SO}_{4}$ solution } & \\
\hline $\mathrm{Ag}$ & \multicolumn{2}{|c|}{$\mathrm{HNO}_{3}$, LIX84-I, HCl } & \\
\hline $\mathrm{Pb}$ & \multicolumn{2}{|c|}{$\mathrm{HNO}_{3}$, LIX84-I, $\mathrm{HCl}, \mathrm{NaOH}$} & \\
\hline $\mathrm{Ag}$ & \multicolumn{2}{|c|}{$\begin{array}{l}1-3 \mathrm{M} \mathrm{HNO}_{3}, 1 \mathrm{M} \mathrm{NaOH} \text { and a sequence of base and acid with water bath and drying in between. } \\
\text { temperature }\left(30^{\circ} \mathrm{C} \text { and } 50^{\circ} \mathrm{C}\right)\end{array}$} & $\begin{array}{l}\text { A. uczyńska- } \\
\text { Łażewska et } \\
\text { al. }(2018)^{11}\end{array}$ \\
\hline
\end{tabular}


Table S4. Recycling rate of Si, Al and Ag at each step of leaching

\begin{tabular}{ccc} 
Element & Recycling rate $(\%)$ & Process step \\
\hline $\mathrm{Si}$ & 99.99 & Complete process \\
$\mathrm{Al}$ & 99.6 & $\mathrm{KOH}$ leaching \\
$\mathrm{Ag}$ & 99.87 & $\mathrm{HNO}_{3}$ Leaching
\end{tabular}

Table S5. Comparison between the electrochemical performances of the Si material prepared in this work and commercial/synthesized Si anode material for Li-ion batteries.

\begin{tabular}{|c|c|c|c|c|}
\hline Reference & Si source & $\begin{array}{l}\text { Capacity }\left(\mathrm{mAh} \mathrm{g}^{-1}\right) \\
\text { of First cycle }\end{array}$ & $\begin{array}{l}\text { Capacity }\left(\mathrm{mAh} \mathrm{g}^{-1}\right) \\
\text { after } 50 \text { cycles }\end{array}$ & $\begin{array}{l}\text { Potential } \\
\text { range(V) }\end{array}$ \\
\hline$\underset{27}{\text { Erk et al. }}$ & $<50 \mathrm{~nm}$ Alfa Aesar & 3650 at $\mathrm{C} / 20$ & 1200 at $\mathrm{C} / 20$ & $0.005-1.0$ \\
\hline $\begin{array}{l}\text { Taiwo et } \\
\text { al. }{ }^{28}\end{array}$ & $\begin{array}{c}\text { Powdered Si (Elkem Silgrain } \\
\text { e-Si, } \mathrm{d}_{50} 3.1 \mathrm{~mm}, 99.7 \% \text { purity) }\end{array}$ & 2700 at $\mathrm{C} / 5$ & 800 at $\mathrm{C} / 5$ & $0.005-1.0$ \\
\hline Sui et al. ${ }^{29}$ & $\begin{array}{l}\text { micro-sized Si powder with } \\
\text { particle size of about } 10 \mu \mathrm{m} \\
(1000 \mathrm{~g}, \text { Xuzhou Lingyun } \\
\text { Silicon Industry Co. Ltd.) }\end{array}$ & 3400 at $0.1 \mathrm{~A} \mathrm{~g}^{-1}$ & 0 (after 20 cycles) & $0.01-1.5$ \\
\hline$\underset{30}{\text { Gan et }}$ al. & $\begin{array}{l}\text { Commercial nano-Si }(>99.9 \% \text {, } \\
1 \text { g, } \sim 30 \text { nm, Shuitian } \\
\text { Materials Technology Co. Ltd, } \\
\text { Shanghai, China) }\end{array}$ & 1030 at $50 \mathrm{~mA} \mathrm{~g}^{-1}$ & $\begin{array}{l}<100 \text { at } 50 \mathrm{~mA} \mathrm{~g}^{-1} \\
\quad(30 \text { cycles })\end{array}$ & $0.01-2.0$ \\
\hline $\begin{array}{l}\text { Graetz et } \\
\text { al. }{ }^{31}\end{array}$ & $\begin{array}{l}\text { Nano-crystalline silicon } \\
\text { prepared by gas-phase } \\
\text { condensation and ballistic } \\
\text { consolidation }\end{array}$ & 2500 at $\mathrm{C} / 4$ & 500 at $\mathrm{C} / 4$ & $0.01-1.5$ \\
\hline Hu et al. ${ }^{32}$ & $\begin{array}{c}99.9 \% \text { pure nano-Si with an } \\
\text { average particle size of } 100 \\
\mathrm{~nm}\end{array}$ & 1200 at $0.4 \mathrm{~mA} \mathrm{~cm}^{-2}$ & 400 at $0.4 \mathrm{~mA} \mathrm{~cm}^{-2}$ & $0.0-2.0$ \\
\hline $\begin{array}{l}\text { Lee et al. } \\
33\end{array}$ & $\begin{array}{c}\text { Si nanoparticle powder }(\leq 100 \\
\mathrm{nm})\end{array}$ & 2250 at $0.1 \mathrm{C}$ & 450 at $0.1 \mathrm{C}$ & $0.0-1.5$ \\
\hline $\begin{array}{l}\text { Wang et } \\
\text { al. }{ }^{34}\end{array}$ & 75 nm Si nanowire network & 1800 at $0.4 \mathrm{~A} \mathrm{~g}^{-1}$ & 0 (after 20 cycles) & $0.01-2$ \\
\hline Li et al. ${ }^{35}$ & $\begin{array}{c}\text { nanometer-scale Si powder } \\
\text { was prepared by laser-induced } \\
\text { silane gas reaction }\end{array}$ & 3000 at $0.1 \mathrm{~mA} \mathrm{~cm}^{-2}$ & $\begin{array}{l}1400 \text { at } 0.1 \mathrm{~mA} \mathrm{~cm}^{-2} \\
\quad \text { (after } 23 \text { cycles) }\end{array}$ & $0.0-0.8$ \\
\hline Ma et al. ${ }^{36}$ & $\begin{array}{l}\text { nest-like Si nanospheres were } \\
\text { prepared by a solvothermal } \\
\text { method }\end{array}$ & 3052 at $2000 \mathrm{~mA} \mathrm{~g}^{-1}$ & 1095 at $2000 \mathrm{~mA} \mathrm{~g}^{-1}$ & $0.02-1.6$ \\
\hline This work & $\begin{array}{l}\text { Nano-structured Si from end- } \\
\text { of-life photovoltaic wafers }\end{array}$ & 2600 at $\mathrm{C} / 20$ & 1400 at $\mathrm{C} / 20$ & $0.01-1$ \\
\hline
\end{tabular}


Study of surface morphology and composition of the two sides of Si wafer after each leaching step:

SEM-EDS measurements were done on wafer fragments before and after leaching process to confirm the results obtained by ICP-MS analysis.

Figure S1 presents the SEM images of back/bottom side of silicon wafers before and after $\mathrm{KOH}$ leaching illustrating that the Al/Al oxide layer with the spherical morphology is efficiently removed.

The SEM-EDS analysis is conducted on back side of silicon wafer before and after $\mathrm{KOH}$ leaching, demonstrating the high efficiency of this process (Figure S2).

Figure S3 presents the SEM images and EDS spectra of front side of silicon wafer a) before and b) after $\mathrm{HNO}_{3}$ leaching
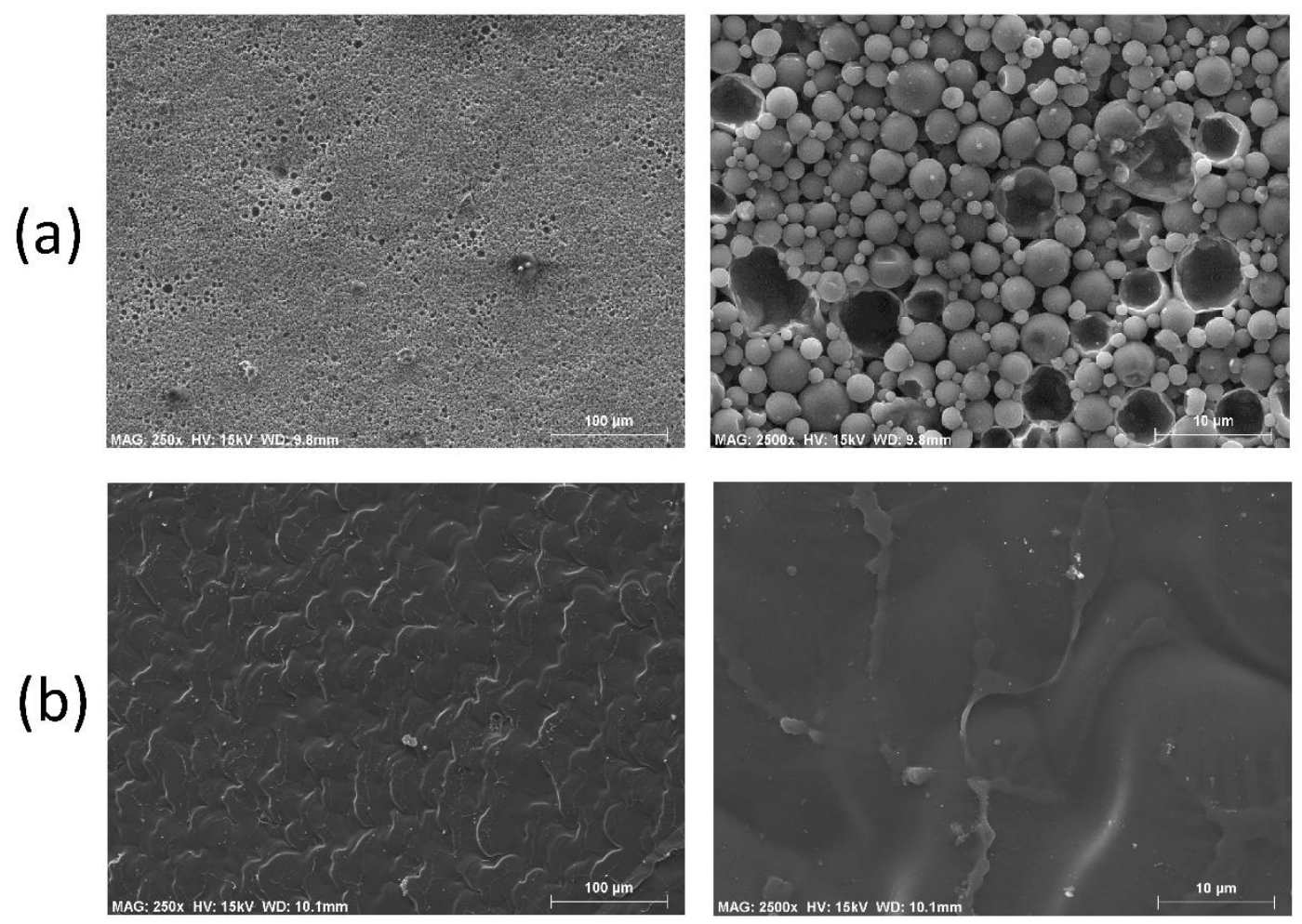

Figure S1. SEM images of back/bottom side of silicon wafer a) before and b) after KOH leaching. 

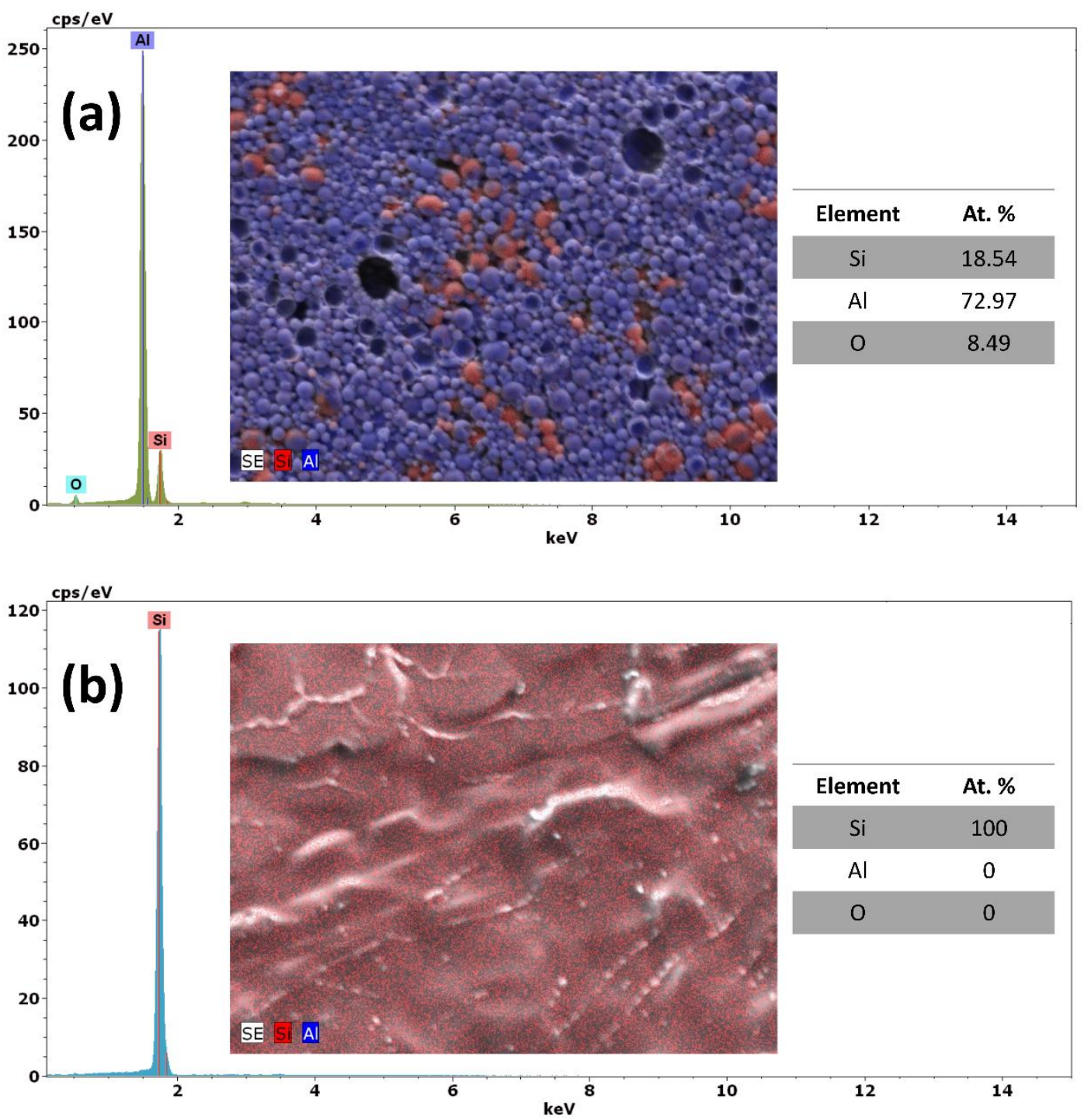

Figure S2. SEM images and EDS spectra of back side of silicon wafer a) before and b) after $\mathrm{KOH}$ leaching. 

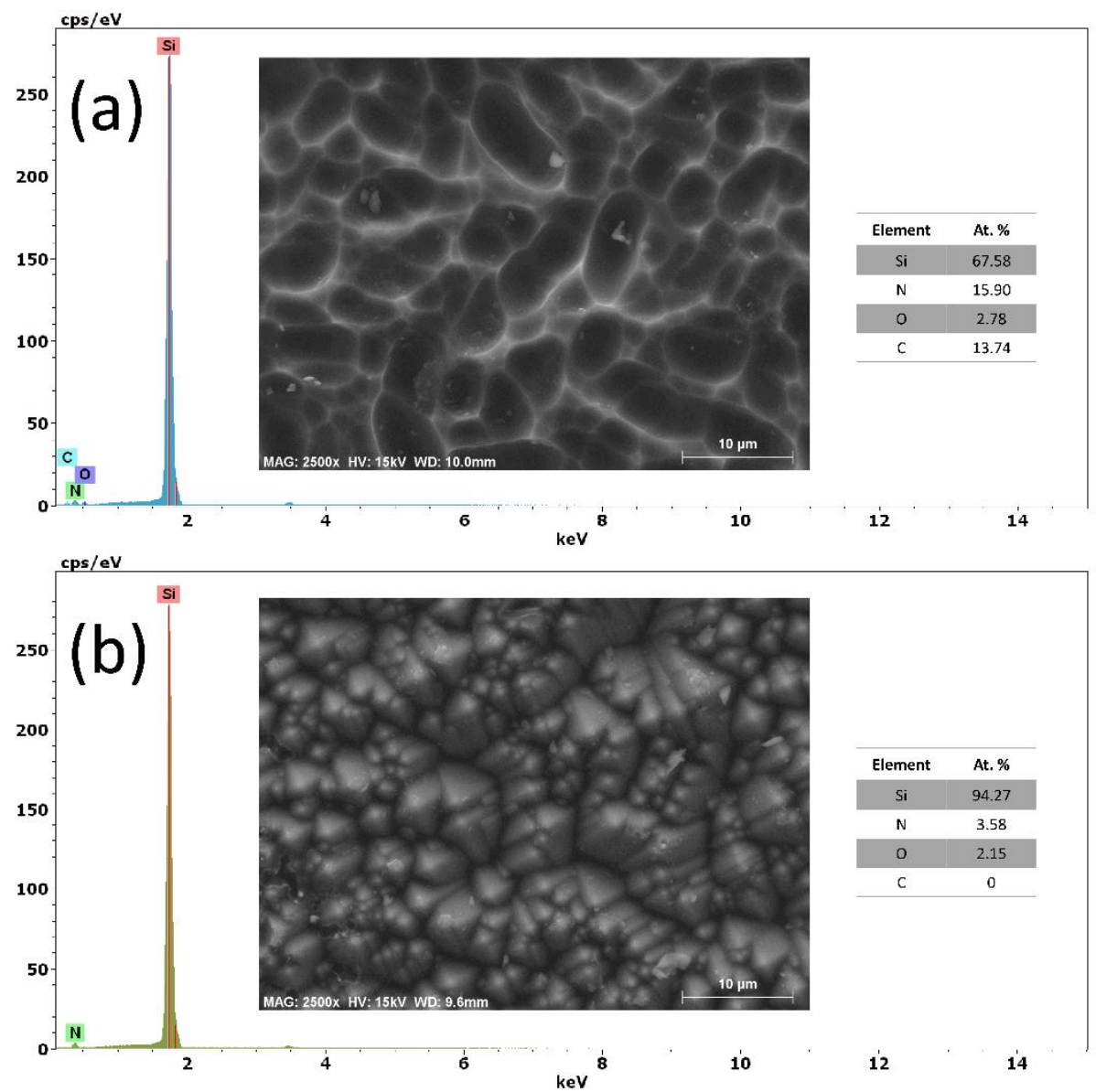

Figure S3. SEM images and EDS spectra of front side of silicon wafer a) before and $\mathbf{b}$ ) after $\mathrm{HNO}_{3}$ leaching 
Study of morphology and composition of the Si powders after pre-grinding and ball milling:
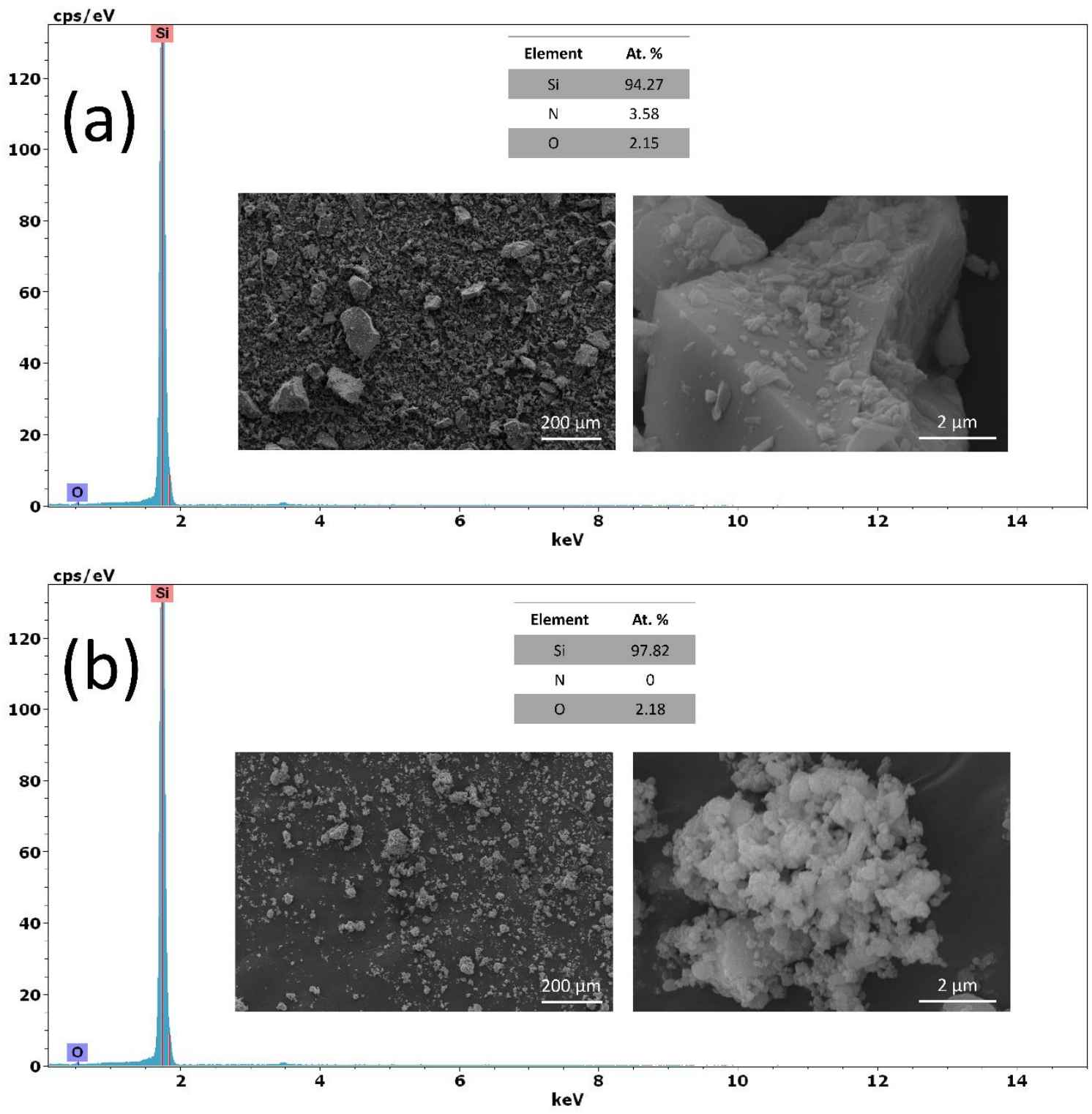

Figure S4. SEM images and EDS spectra of a) pre-grinded Si and b) L-300 sample (ball milling at $300 \mathrm{rpm}$ for $20 \mathrm{~h}$. 


\section{Effect of the ball milling speed on particle size of unleached and leached Si.}

Leached and unleached Si wafer fragments were first pre-grinded to obtain powder with average particle size $<125 \mu \mathrm{m}$ followed by ball milling using a planetary ball mill to further reduce the particle size of Si.
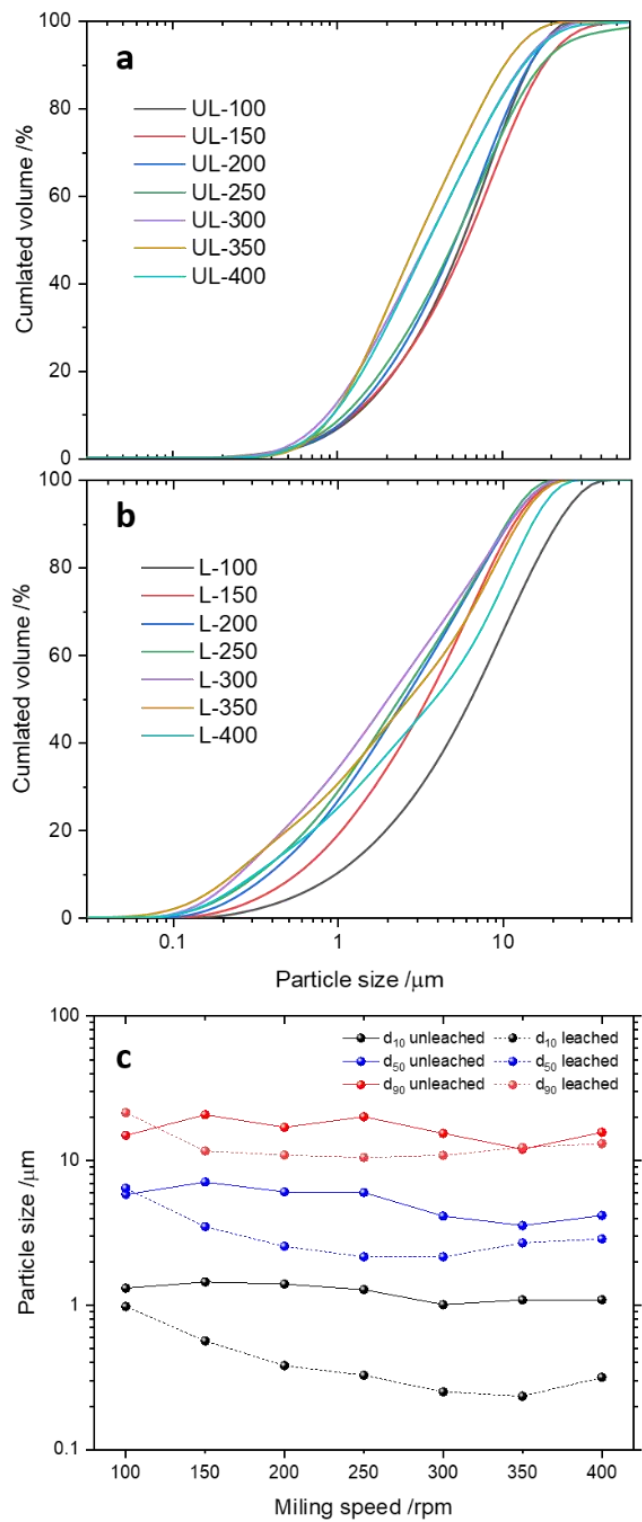

Figure S5. Effect of the ball milling speed: Cumulative volume size distribution of a) unleached Si powder (UL) and b) leached Si powder (L) after 20h of milling at different speeds from 100 rpm to $400 \mathrm{rpm}$. The Evolution of the characteristic sizes $\left(\mathrm{d}_{10}, \mathrm{~d}_{50}\right.$ and $\left.\mathrm{d}_{90}\right)$ of unleached and leached Si milled after $20 \mathrm{~h}$ of milling at different speeds from $100 \mathrm{rpm}$ to $400 \mathrm{rpm}$. 
The milling speed is an important parameter to be considered and optimized to control the structural and morphological properties of the particle. Figure 2, illustrates the evolution of the particle-size with milling time in the pre-grinding step, XRD patterns, SEM micrographs, particle size distribution and BET specific surface area of unleached and leached Si after ball milling at different speeds.

To further highlight the difference in the efficiency of ball milling in unleached and leached samples, the particle size distribution is expressed with cumulated volume as a function of particle size in Figure S5. The cumulative volume increases for small particles in leached Si by increasing the milling speed which is illustrated by the clear shift of the curve toward left (lower particle sizes). The evolution of characteristic sizes $\left(d_{10}, d_{50}\right.$ and $\left.d_{90}\right)$ also shows a major increase in $d_{10}$ for leached Si (Figure S5c). 
The SEM images with higher magnification and TEM images in Figure S6 illustrate that the aggregates in the SEM images are constituted of nano particles.
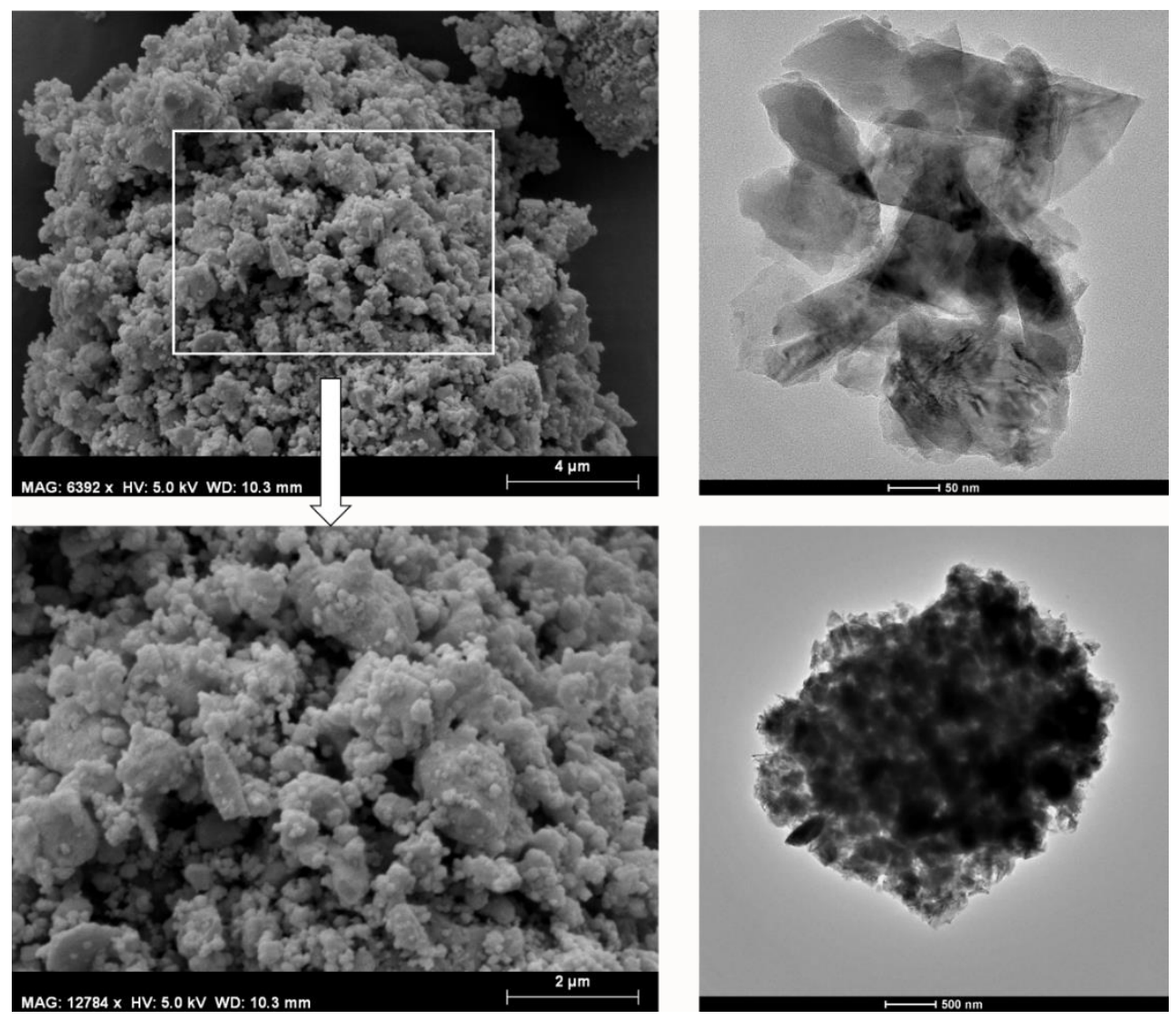

Figure S6. SEM and TEM images of L-250 samples showing the presence of nanoparticles along with micrometric/sub-micrometric particles. 


\section{Electrochemical measurements of unleached/leached Si powder with different ball milling}

speed

Electrochemical measurements were conducted in two-electrode coin cells, using lithium metal foil as counter electrode material and $1 \mathrm{M} \mathrm{LiPF}_{6}$ in ethylene carbonate/dimethyl carbonate (EC:DMC 1/1, v/v) with 10wt \% FEC and $2 \mathrm{wt} \% \mathrm{VC}$ as electrolyte. Silicon sample as active material was mixed with carbon black $(\mathrm{CB})$ and CarboxyMethyl cellulose (CMC) in 1:1:1 ratio and then mixed in water for 2 hours and spread on a $\mathrm{Cu}$ foil substrate. The electrodes were dried for $12 \mathrm{~h}$ at $110{ }^{\circ} \mathrm{C}$ under vacuum to remove the water. The electrodes were then cut into disks with 12.6 $\mathrm{mm}$ in diameter (active mass of approximately 1-2 mg). The current collectors were stainless steel and the separator between electrodes was a $25 \mu \mathrm{m}$ monolayer polypropylene membrane (Celgard 2500). All the assembly processes for the coin cells were conducted in an argon-filled glove box. All cells were tested within a fixed voltage window, between 0.01 and $1.0 \mathrm{~V} \mathrm{vs.} \mathrm{Li}^{+} / \mathrm{Li}^{0}$ in galvanostatic mode ( $1 \mathrm{C}$ corresponds to the current for $\mathrm{x}=1$ in $\mathrm{Li}_{\mathrm{x}} \mathrm{Si}$ in $1 \mathrm{~h}$ ), using the BTS4000 Neware Electrochemical Test System. All electrochemical tests were carried out at room temperature. 


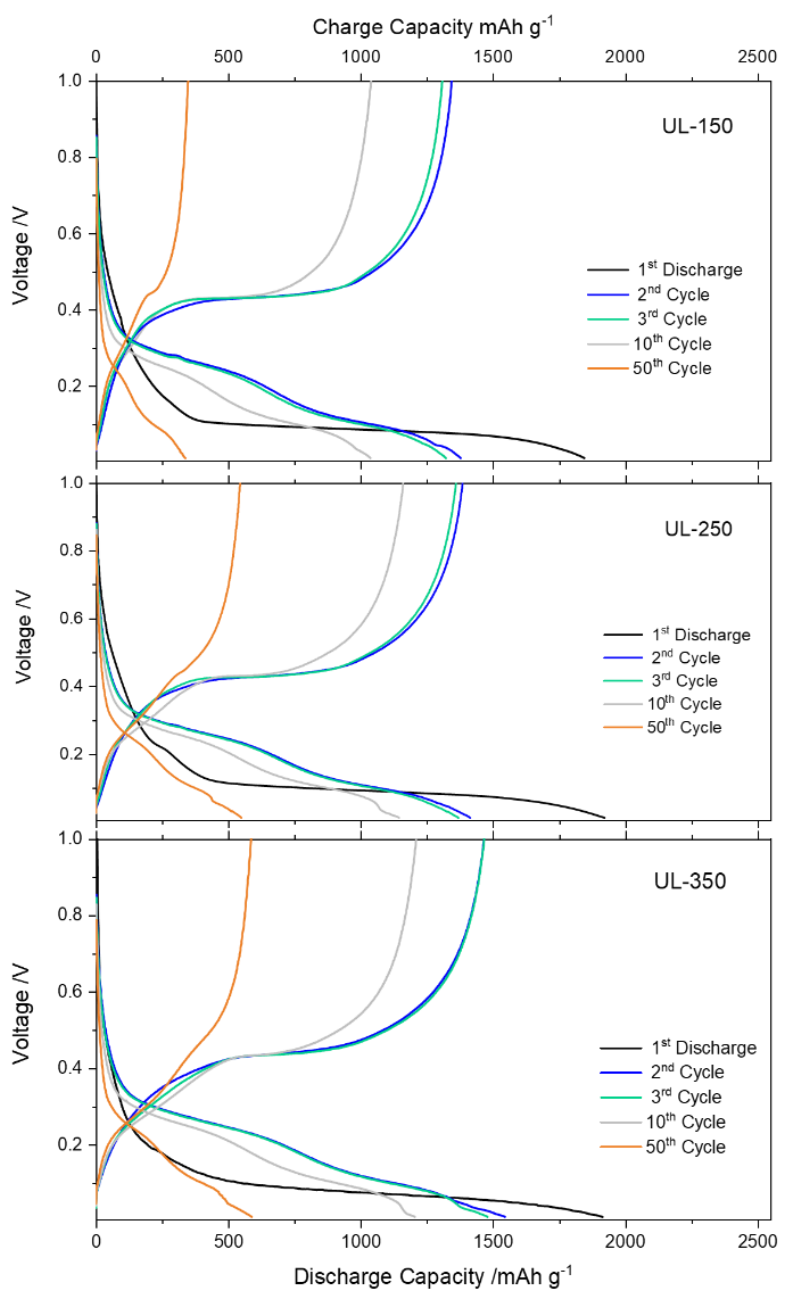

Figure S7. Voltage profile recorded at $0.05 \mathrm{C}$ of $1^{\text {st }}, 2^{\text {nd }}, 3^{\text {rd }}, 10^{\text {th }}$ and $50^{\text {th }}$ cycles in unleached samples U-150, U-250 and U-350. 


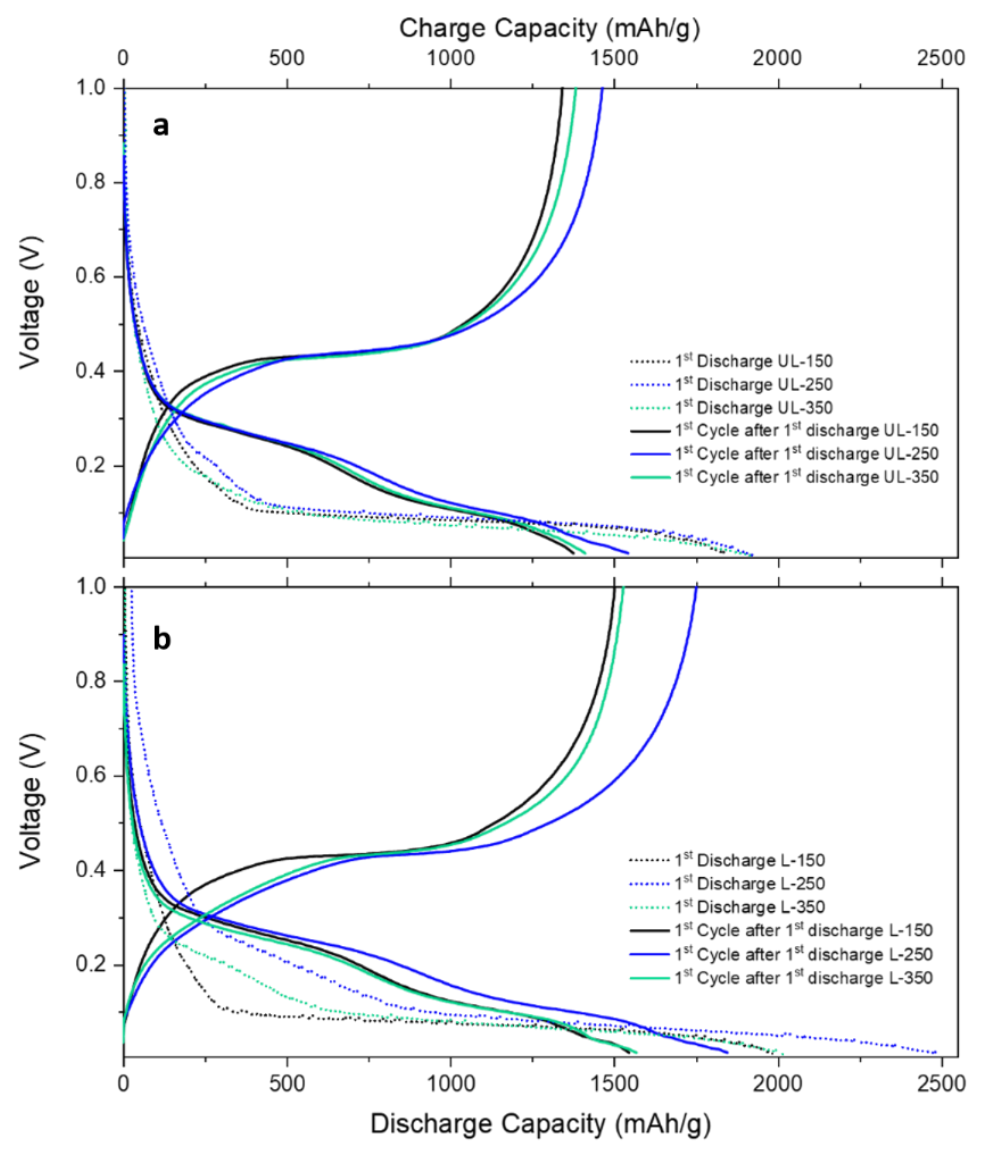

Figure S8. Voltage profile recorded at $0.05 \mathrm{C}$ of first lithiation and following cycle in a) unleached samples UL-150, UL-250 and UL-350; b) leached samples L-150, L-250 and L-350. 
SEM images of leached Si based electrodes before cycling, after lithiation, and after delithiation:
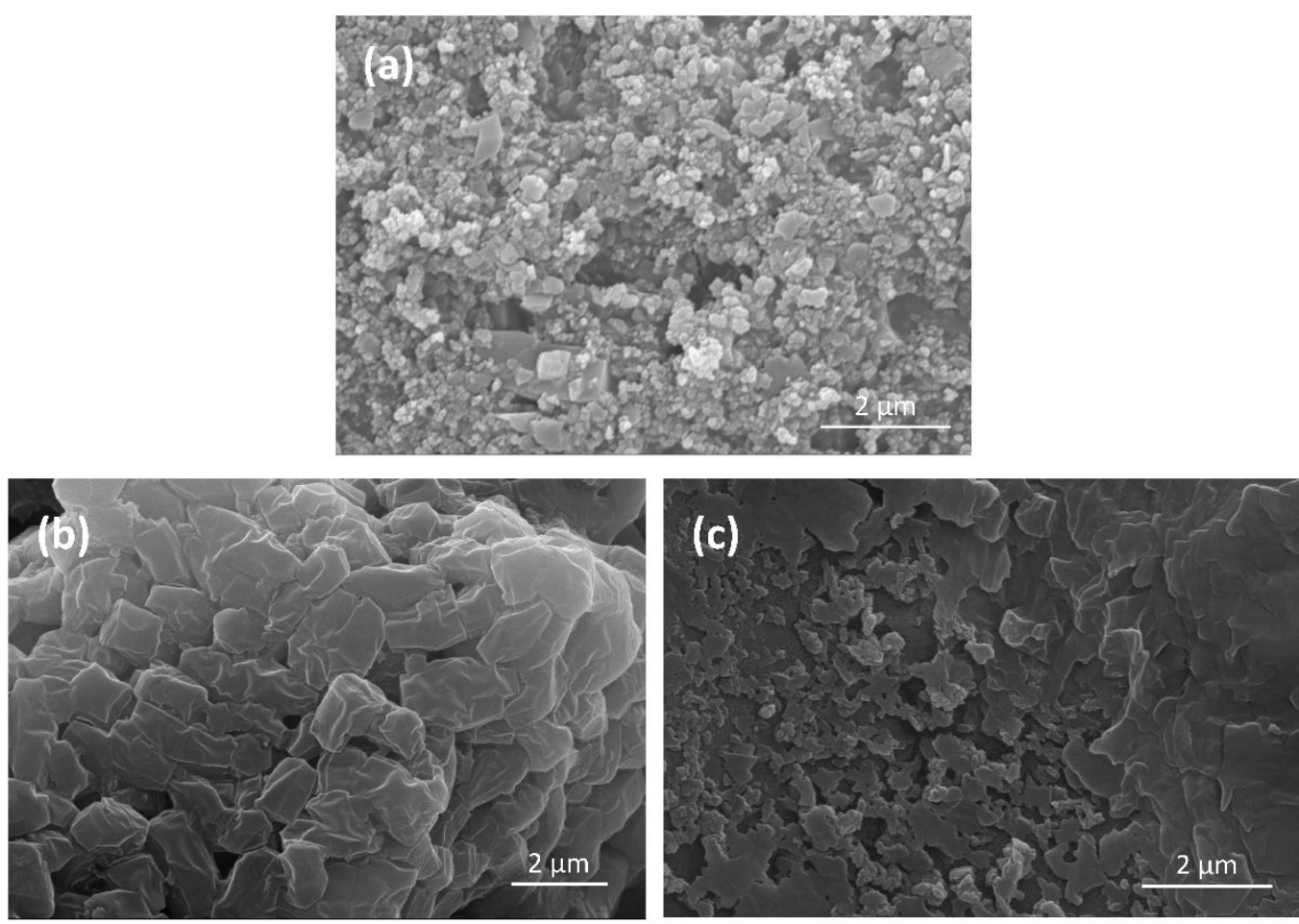

Figure S9. SEM images of leached Si based electrodes a) before cycling, b) after lithiation, and c) after delithiation. 
Effect of Ball milling duration on structure and morphology of recovered silicon milled during different durations which ranged from 1 to $40 \mathrm{~h}$, for $B P R$ ratio $=10$
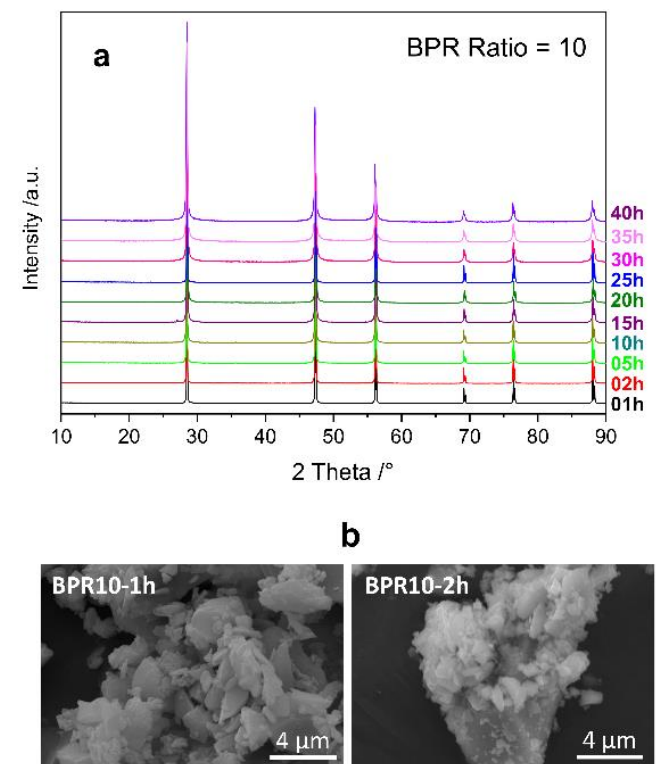

b
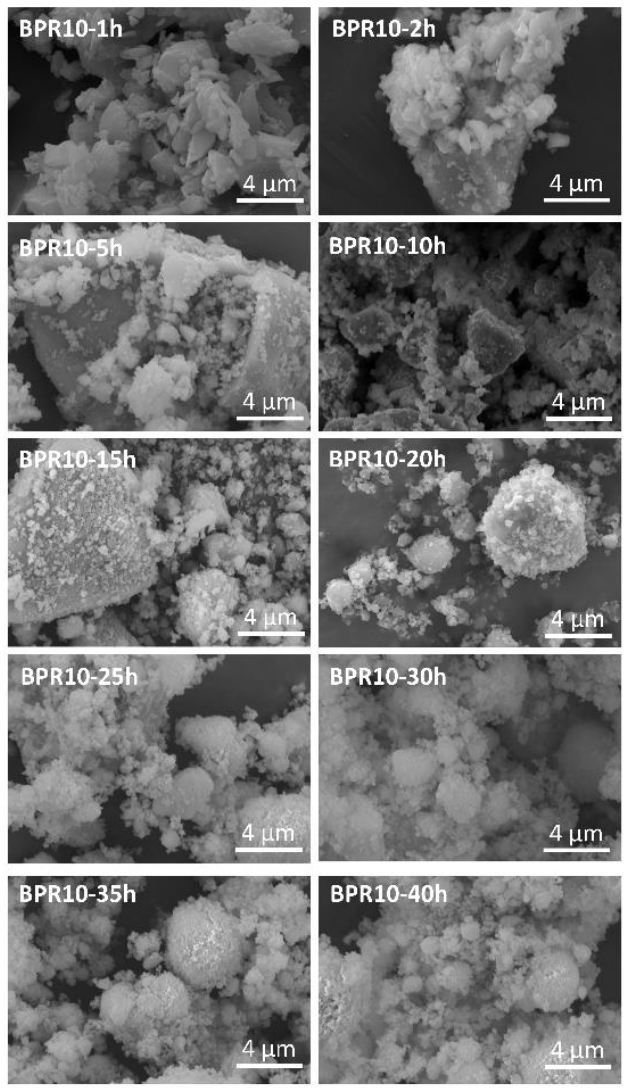

Figure S10. Effect of Ball milling duration: a) Similar XRD patterns were obtained for all the milled powders with BPR Ratio=10. b) SEM images of the recovered silicon milled during different durations which ranged from 1 to $40 \mathrm{~h}$, for BPR ratio $=10$ show quite similar morphologies at each time step to samples milled with $\mathrm{BPR}=5$. 

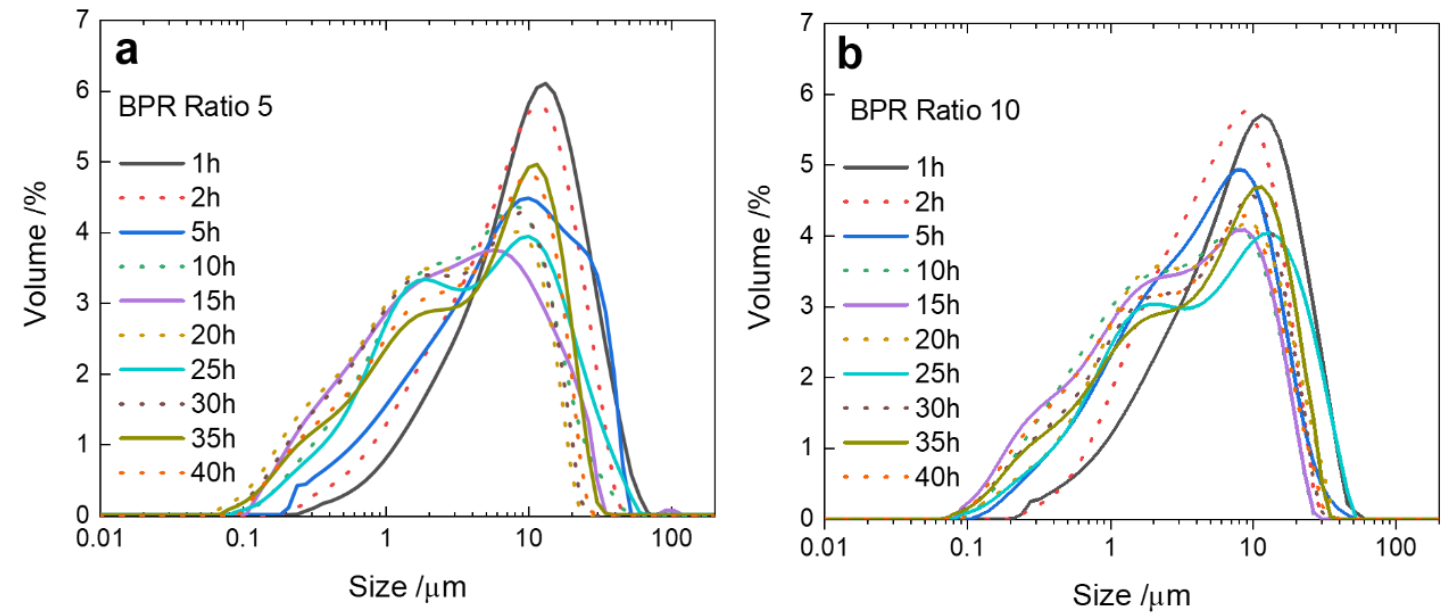

Figure S11. The particle-size distribution of the recovered silicon milled during different durations which ranged from 1 to $40 \mathrm{~h}$ with a) 5 and b) 10 ball-to-powder ratios. 

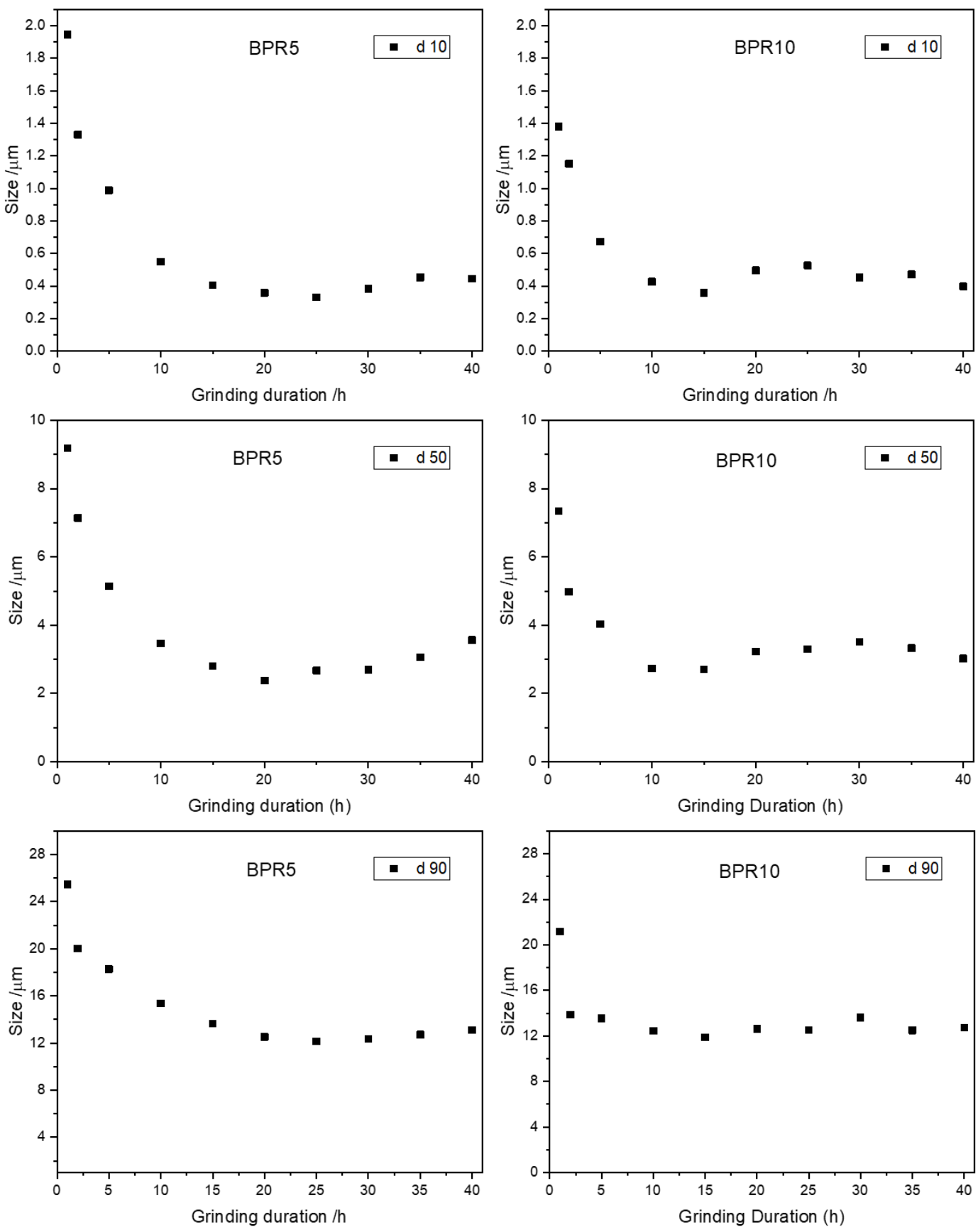

Figure S12. Evolution of the characteristic sizes $\left(\mathrm{d}_{10}, \mathrm{~d}_{50}\right.$ and $\left.\mathrm{d}_{90}\right)$ of Si milled during different durations (1 to 40h) with BPR: 5 and BPR: 10. 


\section{References}

(1) Klugmann-Radziemska, E.; Ostrowski, P.; Drabczyk, K.; Panek, P.; Szkodo, M. Experimental Validation of Crystalline Silicon Solar Cells Recycling by Thermal and Chemical Methods. Sol. Energy Mater. Sol. Cells 2010, 94 (12), 2275-2282. https://doi.org/10.1016/j.solmat.2010.07.025.

(2) Park, J.; Park, N. RSC Advances Wet Etching Processes for Recycling Crystalline Silicon Solar Cells from End-of-Life Photovoltaic Modules. RSC Adv. 2014, 4, 34823-34829. https://doi.org/10.1039/C4RA03895A.

(3) Shin, J.; Park, J.; Park, N. A Method to Recycle Silicon Wafer from End-of-Life Photovoltaic Module and Solar Panels by Using Recycled Silicon Wafers. Sol. Energy Mater. Sol. Cells 2017, $162 \quad$ (December 2016), 1-6. https://doi.org/10.1016/j.solmat.2016.12.038.

(4) Klugmann-Radziemska, E.; Ostrowski, P. Chemical Treatment of Crystalline Silicon Solar Cells as a Method of Recovering Pure Silicon from Photovoltaic Modules. Renew. Energy 2010, 35 (8), 1751-1759. https://doi.org/10.1016/j.renene.2009.11.031.

(5) Kang, S.; Yoo, S.; Lee, J.; Boo, B.; Ryu, H. Experimental Investigations for Recycling of Silicon and Glass from Waste Photovoltaic Modules. Renew. Energy 2012, 47, 152-159. https://doi.org/10.1016/j.renene.2012.04.030.

(6) Lee, J. K.; Lee, J. S.; Ahn, Y. S.; Kang, G. H.; Song, H. E.; Lee, J. I.; Kang, M. G.; Cho, C. H. Photovoltaic Performance of C-Si Wafer Reclaimed from End-of-Life Solar Cell Using Various Mixing Ratios of HF and HNO3. Sol. Energy Mater. Sol. Cells 2017, 160 (July 
2016), 301-306. https://doi.org/10.1016/j.solmat.2016.10.034.

(7) Yi, Y. K.; Kim, H. S.; Tran, T.; Hong, S. K.; Kim, M. J. Recovering Valuable Metals from Recycled Photovoltaic Modules. J. Air Waste Manag. Assoc. 2014, 64 (7), 797-807. https://doi.org/10.1080/10962247.2014.891540.

(8) Takami, K.; Kobashi, M.; Shiraga, Y.; Uddin, M. A.; Kato, Y.; Wu, S. Effect of HF and HNO3 Concentration on Etching Rate of Each Component in Waste Crystalline Silicon Solar Cells. Mater. Trans. 2015, $56 \quad$ (12), 2047-2052. https://doi.org/10.2320/matertrans.M2015293.

(9) Park, J.; Kim, W.; Cho, N.; Lee, H.; Park, N. An Eco-Friendly Method for Reclaimed Silicon Wafers from a Photovoltaic Module: From Separation to Cell Fabrication. Green Chem. 2016, 18 (6), 1706-1714. https://doi.org/10.1039/c5gc01819f.

(10) Jung, B.; Park, J.; Seo, D.; Park, N. Sustainable System for Raw-Metal Recovery from Crystalline Silicon Solar Panels: From Noble-Metal Extraction to Lead Removal. ACS Sustain. Chem. Eng. 2016, $4 \quad$ (8), 4079-4083. https://doi.org/10.1021/acssuschemeng.6b00894.

(11) Kuczyńska-Łażewska, A.; Klugmann-Radziemska, E.; Sobczak, Z.; Klimczuk, T. Recovery of Silver Metallization from Damaged Silicon Cells. Sol. Energy Mater. Sol. Cells 2018, 176 (December 2017), 190-195. https://doi.org/10.1016/j.solmat.2017.12.004.

(12) Erk, C.; Brezesinski, T.; Sommer, H.; Schneider, R.; Janek, J. Toward Silicon Anodes for Next-Generation Lithium Ion Batteries: A Comparative Performance Study of Various Polymer Binders and Silicon Nanopowders. ACS Appl. Mater. Interfaces 2013, 5 (15), 
7299-7307. https://doi.org/10.1021/am401642c.

(13) Taiwo, O. O.; Loveridge, M.; Beattie, S. D.; Finegan, D. P.; Bhagat, R.; Brett, D. J. L.; Shearing, P. R. Investigation of Cycling-Induced Microstructural Degradation in SiliconBased Electrodes in Lithium-Ion Batteries Using X-Ray Nanotomography. Electrochim. Acta 2017, 253, 85-92. https://doi.org/10.1016/j.electacta.2017.08.161.

(14) Sui, D.; Xie, Y.; Zhao, W.; Zhang, H.; Zhou, Y.; Qin, X.; Ma, Y.; Yang, Y.; Chen, Y. A High-Performance Ternary Si Composite Anode Material with Crystal Graphite Core and Amorphous Carbon Shell. J. Power Sources 2018, 384 (November 2017), 328-333. https://doi.org/10.1016/j.jpowsour.2018.03.008.

(15) Gan, L.; Guo, H.; Wang, Z.; Li, X.; Peng, W.; Wang, J.; Huang, S.; Su, M. A Facile Synthesis of Graphite/Silicon/Graphene Spherical Composite Anode for Lithium-Ion Batteries. Electrochim. Acta 2013, 104, 117-123. https://doi.org/10.1016/j.electacta.2013.04.083.

(16) Graetz, J.; Ahn, C. C.; Yazami, R.; Fultz, B. Highly Reversible Lithium Storage in Nanostructured Silicon. Electrochem. Solid-State Lett. 2003, 6 (9), A194. https://doi.org/10.1149/1.1596917.

(17) Hu, R.; Sun, W.; Chen, Y.; Zeng, M.; Zhu, M. Silicon/Graphene Based Nanocomposite Anode: Large-Scale Production and Stable High Capacity for Lithium Ion Batteries. $J$. Mater. Chem. A 2014, 2 (24), 9118-9125. https://doi.org/10.1039/c4ta01013b.

(18) Lee, J. K.; Yoon, W. Y.; Kim, B. K. Electrochemical Behavior of Si Nanoparticle Anode Coated with Diamond-Like Carbon for Lithium-Ion Battery. J. Electrochem. Soc. 2012, 159 
(11), A1844-A1848. https://doi.org/10.1149/2.045211jes.

(19) Wang, W.; Tian, M.; Wei, Y.; Lee, S. H.; Lee, Y. C.; Yang, R. Binder-Free ThreeDimensional Silicon/Carbon Nanowire Networks for High Performance Lithium-Ion Battery Anodes. Nano Energy 2013, 2 (5), 943-950. https://doi.org/10.1016/j.nanoen.2013.03.015.

(20) Li, H.; Huang, X.; Chen, L.; Wu, Z.; Liang, Y. High Capacity Nano-Si Composite Anode Material for Lithium Rechargeable Batteries. Electrochem. Solid-State Lett. 1999, 2 (11), 547-549. https://doi.org/10.1149/1.1390899.

(21) Ma, H.; Cheng, F.; Chen, J.; Zhao, J.; Li, C.; Tao, Z.; Liang, J. Nest-like Silicon Nanospheres for High-Capacity Lithium Storage. Adv. Mater. 2007, 19 (22), 4067-4070. https://doi.org/10.1002/adma.200700621. 